\title{
Study of Flexible Polyurethane Foams Reinforced with Coir Fibres and Tyre Particles
}

\author{
Chan Wen Shan, Maizlinda Izwana Idris, and Mohd Imran Ghazali
}

\begin{abstract}
In this paper, the use of coir fibres and tyre particles, as fillers reinforced the flexible polyurethane (PU) foams were developed and analyzed. The characteristics of fillers were examined by SEM, XRF and TGA. There are five types of foam composites were produced by one-shot free rising method in closed mould. The results of XRF trace of $\mathrm{CH}_{2}$ revealed more than $99 \%$ in coir is organic compounds whereas $\mathbf{9 6 . 9 \%}$ in tyre are formed by aromatic oil, carbon black and rubber hydrocarbon (RHC). Besides, the results of thermal analysis indicated coir fibres and tyre particles are suitable to use as fillers for $\mathrm{PU}$ foams since they have high decomposition temperature, which is $250^{\circ} \mathrm{C}$ for coir and $350^{\circ} \mathrm{C}$ for rubber elements in tyre. During foam composites production, the viscosity created causes only $2.5 \mathrm{wt} \%$ of fillers was added to flexible PU foams in this study. The viscosity damage the foaming ability and foaming rate of composites. However, the results of morphology studied shown foam composites having cellular structure of smaller cell size and thus having higher cell density. This type of structure may provide a better damping for energy absorption according to literatures.
\end{abstract}

Index Terms-Coir fibres, flexible polyurethane foam, recycled tyre, structure.

\section{INTRODUCTION}

Flexible polyurethane (PU) foam is one of the major productions from urethane material [1]. It is basically produced by polyol, isocyanate, water, catalyst, and surfactant. Among all, polyol and isocyanate are mixed to form polyurethane linkage [2]. Other components such as: water is added as blowing agent for foam foaming; Catalyst and surfactant are function as promoting nucleation as well as stabilizing the foam formation during foam development stage [2]. Flexible PU foam is widely used in many applications. Generally, it is used as cushioning material for automotive seat, mattress, furniture, and in packaging system. Besides, it also used as clothing or diapers in our daily life. To our knowledge, this material has become such widely used because of its excellent light weight, strength to weight ratio performance, and the most important is, it offer degree of comfort, protection and utility not matched by other single

Manuscript received March 22, 2012; revised March 25, 2012. This work was supported in part by the Office for Research, Innovation, Commercialization, Consultancy Management (ORICC), Universiti Tun Hussein Onn Malaysia, under short grant Vot No. 0896.

W. S. Chan is a master candidate from Faculty of Mechanical and Manufacturing Engineering, Universiti Tun Hussein Onn Malaysia, 86400 Parit Raja, Batu Pahat, Johor, Malaysia (e-mail: shan57p@yahoo.com).

M. I. Idris is a senior lecturer (doctorial) with the Department of Materials and Design Engineering, Universiti Tun Hussein Onn Malaysia, 86400 Parit Raja, Batu Pahat, Johor, Malaysia (e-mail: izwana@uthm.edu.my).

M. I. Ghazali is a senior lecturer (professor) with the Department of Engineering Mechanics, Universiti Tun Hussein Onn Malaysia, 86400 Parit Raja, Batu Pahat, Johor, Malaysia (e-mail: imran@uthm.edu.my). material [2]-[4].

Flexible PU foam is found on having open-cells cellular structure. It is usually consists of a minimum of two phases which is a solid polymer matrix and a gaseous phase derived from carbon dioxide $\left(\mathrm{CO}_{2}\right)$ [3]. There is also possible to have more than one solid phase occurs in foam. It is normally presented in the form of fillers with fibrous, particles and other shape size. In recent time, it was observed that fined fillers such as post-consumer PET particle, carbon nanotube, calcite $\left(\mathrm{CaCO}_{3}\right)$, dolomite $\left(\mathrm{CaMg}\left(\mathrm{CO}_{3}\right)_{2}\right)$, calcium carbonate, and fumed silica are added to flexible PU foams for recycling, cost reduction, mechanical properties, and acoustic capability enhancement [4]-[8]. These studies revealed the possibility of incorporate fillers in flexible PU foams and it have been attracted researchers on foam composite production actually; since the fluctuation of oil price causes the price rising in petrol chemical based stocks e.g. polyol and isocyanate [5], [8]. Replaced part of the PU foam derivatives with fillers could at least reduce the cost of foam production, as long as the desired characteristics of foam are retained [5], [8].

Substitution of pure resin by recycled materials is a worldwide tendency, due to the growing of environmental awareness. Coir fibre is a coarse and short fibre which extracted from the fibrous outer shell of coconut. It is considered as environmental friendly, biodegradable, abundant available, cheap and low density [9]. Recycled tyre is basically made with natural rubber (latex) and synthetic rubber $(S B R, B R$, and IIR). It was obtained once a tyre is permanent removed from a vehicle. Hence, it is a waste and usually followed another route such as recycling after that. It was reported that post-consumer tyres were not classified as hazardous or dangerous material [10]. According to the literature, coir is found on taking long time to decay and thus created a problem on conveniently dispose of this waste [11]. For post-consumer tyre, their recycling methods are very limited. Most of them are actually not in used and stored in warehouse or derelict building, on farms, or scattered around the countryside and in rivers [10]. This causes a great pollution to the environment. Thus, in order to minimize the environmental problems, an alternative recycling method that is mixing coir fibre and recycled tyre with flexible PU foams to formed composites was developed in previous work [12].

Fillers are not generally used to improve the mechanical or dynamic properties of pure resin but, rather, are used to enhance other aspect of composite behavior such as recycling and cost reduction [13]. For coir fibres and tyre particles, there are many studies showed that reinforced the pure polymer with these fillers can achieved a good damping property [14]-[16]. Nevertheless, the mechanical properties in composite with coir fibres added could be enhanced via using treated coir [14], [17]. Further, few studies have been 
indicated that presence of waste tyre rubber or particular fillers can developed a cellular structure which is good in damping performance [7], [18]. As summary, incorporate coir fibres and recycled tyre in flexible PU foam may given the benefits of recycling, cost reduction, as well as properties enhancement in foam and these have been proven on previous works [12], [19].

Therefore, in this paper, the use of coir fibres and tyre particles as fillers add in flexible PU foams are described in details. Compare with the previous works, the preparations of coir fibres and tyre particles to make foam composites are described. The structure, chemical composition, and thermal properties of fillers are examined. Besides, the effect of fillers to foam composites production and its micro-cellular structure are investigated also.

\section{EXPERIMENTAL STUDY}

\section{A. Materials}

- A liquid mixture with polyether polyol, amine catalyst, water, surfactant (density at $25^{\circ} \mathrm{C}=1.02 \mathrm{~g} / \mathrm{cm}^{3}$, viscosity at $25^{\circ} \mathrm{C}=650-750 \mathrm{cps}$ );

- Polymethane polyphenyl isocyanate (Modified polymeric-MDI) (viscosity at $25^{\circ} \mathrm{C}=120-160 \mathrm{cps}$, specific gravity at $25^{\circ} \mathrm{C}=1.18-1.20 \mathrm{~g} / \mathrm{ml}, \mathrm{NCO}$ content, $\% \mathrm{wt}=26.3-27.3)$;

- Coir fibres with length of $0.1 \mathrm{~mm}-5 \mathrm{~mm}$;

- Recycled truck tyre with 80 mesh particle size; and

- Distilled water.

\section{B. Preparation}

The coir fibres which collected from polymer and ceramic laboratory, UTHM were initially chopped to short length by using granulator machine. The short fibres with length of $10-15 \mathrm{~mm}$ were found after chopped (Fig. 1(a)). The short fibres were then ready for alkaline treatment. The objective of fibres treatment was to remove the dirt layer on the surface of coir so that it can be well bond with PU resin in composites formation [14], [17].

Based on Fig. 2, the treatment process start with immersed the short coir fibres in alkaline solution of $5 \% \mathrm{NaOH}+95 \%$ water at room temperature for 24 hours. The fibres were then rinsed with water and distilled water (at the final rinsed) for the purpose of removed the dirt layer and neutralized the fibres to $\mathrm{pH} 7$. In $3^{\text {rd }}$ step, the treated coir fibres were sending to oven with temperature of $70^{\circ} \mathrm{C}$ for dried. 24 hours were needed for the fibres drying process.
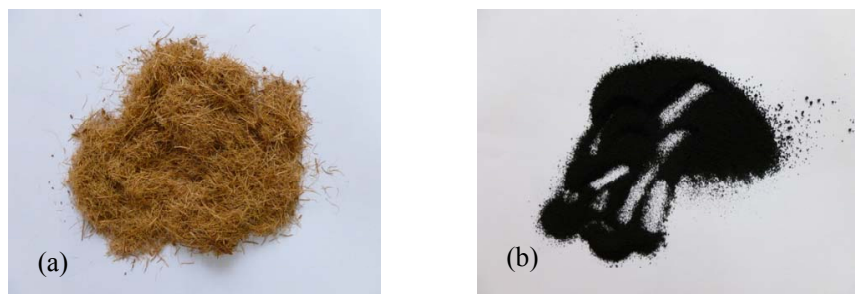

Fig. 1. (a) Coir fibres, and (b) tyre particles.

At the end, the treated coir fibres were chopped again to reach $0.1-5 \mathrm{~mm}$ length by using rotor milled machine before they are use in composites fabrication. The structures of untreated and treated coir fibre can be seen at Fig. 4(a) and 4(b) in section of results and discussion.

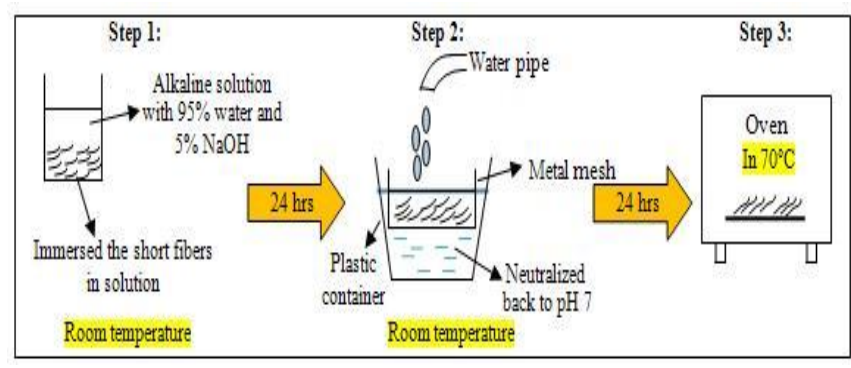

Fig. 2. Coir fibres treatment process.

For tyre particles, there was no any resizing or treatment process was conducted to this filler. They are directly obtained from Yong Fong Rubber Industries. As mentioned before, the tyre particles were ready in 80 mesh particles size with chemical composition of: acetone extract $=10 \pm 3 \%$, ash content $8 \pm 3 \%$, carbon black $=30 \pm 5 \%$, and rubber hydrocarbon $(\mathrm{RHC})=52 \pm 5 \%$. Fig. 1 (b) shows the image of tyre particles in powder form.

\section{Foams Production}

There are five different types of foam composites were designed and developed in this study. The formula of foam composites formation can be seen in Table I. Similar with many literatures, the flexible PU foam composites were produced manually using a mould [5], [6], [8]. However, in here, there was a closed-mould using for foams fabrication as compare with those using the open-mould in literatures [5] [6], [8]. Fig. 3 illustrated the designs of closed-mould. The mould was making by carbon steel. The base and male parts of mould were closed by M6 threaded screw whereas the M10 threaded holes were designed for open the base and male parts by jet it using M10 screws.

TABLE I: FORMATION OF FOAM COMPOSITES DESIGNED

\begin{tabular}{clcc}
\hline Sample & \multicolumn{1}{c}{ Foam Composites } & $\begin{array}{c}\text { PU Content } \\
{[\mathrm{wt} \%]}\end{array}$ & $\begin{array}{c}\text { Fillers } \\
{[\mathrm{wt} \%]}\end{array}$ \\
\hline A & Pure PU (reference) & 100 & - \\
B & With treated coir fibres (F) & & \\
C & With tyre particles (P) & & 2.5 \\
D & With 50\%F50\%P (50F50P) & 97.5 & \\
E & With $80 \% \mathrm{~F} 20 \% \mathrm{P}(80 \mathrm{~F} 20 \mathrm{P})$ & & \\
F & With $80 \% \mathrm{P} 20 \% \mathrm{~F}(80 \mathrm{P} 20 \mathrm{~F})$ & & \\
\hline
\end{tabular}

As described in previous work, the foam composites were produced by one-shot free rising method using the closed-mould with core size of $100 * 100 * 60 \mathrm{~mm}$ [12]. Initially, all the components listed in sub-section of Materials were weighing according to the formula shown in Table I. The weight percentage, wt $\%$ of each component was calculated based on the target density set for foam composites that is $60 \mathrm{~kg} / \mathrm{m}^{3}$. The PU content shows in Table I was prepared in blend ratio of 100:60:3 that is polyol: isocyanate: distilled water. In overall, the production routes for the foam composites production were followed as:

1. The polyol, distilled water, and fillers were initially stirred with a Philips multiple speeds handmixer in a cup for 1 minute.

2. Isocyanate was poured into polyol mixture and stirred 
about 10 seconds.

3. The mixtures were then immediately poured into mould and closed the mould before the foam is expanded out.

4. After 15 minutes, the foam composite can be removed from mould. It was left for 24 hours to reach cured. For pure PU foam, similar production routes described as above were followed.

\section{Characterization Methods}

The structure of fillers and foam composites were examined by using Scanning Electron Microscopy (SEM) of JEOL-JSM6380LA at $10-15 \mathrm{kV}$ after the fillers and foams coated with thin layer platinum by Auto Fined Coater of JEOL-JFC1600. For foam type specimens, they have to prepare in $5 * 5 * 5 \mathrm{~mm}$ in order to fit with the specimen holder used in SEM. The small foams were mounted on the holder using a double side carbon tape. During the SEM examined, the mean cell size of foam structure was measured directly according the micrograph captured using analytical SEM software. All the mean cell size values of foam composites were average from 20 cell diameters.

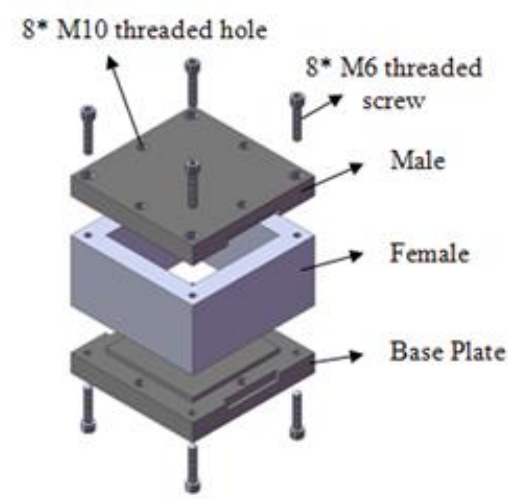

Fig. 3. Designs of closed-mould.

Thermogravimetric analysis (TGA) was carried out using Linseis TGA for characterized the thermal properties of fillers. The analysis was performed under air atmosphere. The fillers were heated from $0^{\circ} \mathrm{C}$ to $800^{\circ} \mathrm{C}$ at a heating rated of $10 \mathrm{~K} / \mathrm{min}$. At the end, the thermal profiles of coir fibres and tyre particles were obtained in TG and Derivative TG curves using TG analyzed software.

Chemical composition of coir fibres and tyre particles were trace by using $X$-Ray Fluorescence (XRF) method. The testing was performed by XRF machine " $S 4$ pioneer" which is product from Bruker AXS from Germany.

\section{RESUlTS AND DisCUSSION}

\section{A. Structure of Fillers}

Fig. 4(a) and 4(b) present the surface characteristic of untreated and treated coir fibres. Based on the images, one may noticed that the surface of untreated coir is covered with a layer of substances, and these may include pectin, lignin, and other impurities on its surface [20]. Naturally, coir fibre is form by lignin $(40-45 \%)$, cellulose $(32-43 \%)$, moisture $(8 \%)$, pectin $(3-4 \%)$, and hemicelluloses $(0.15-0.25 \%)$ [9]. However, after the alkaline treatment, the surface of coir fibre become rough and contained many pits (refers to Fig. 4(b)). The results indicated that the alkaline treatment with $5 \% \mathrm{NaOH}$ added was helps on removed the dirt or impurities layer on coir surface and, it is actually good for composite formation since the pits found on treated fibres would promote a better bonding between matrix and fibres during the composite formation [14], [20]. Thus, problem of fillers losses or leakage will not be happen on production stage. Rather, a good bonding between fillers and matrix can help on improve the mechanical properties of material [14], [17].

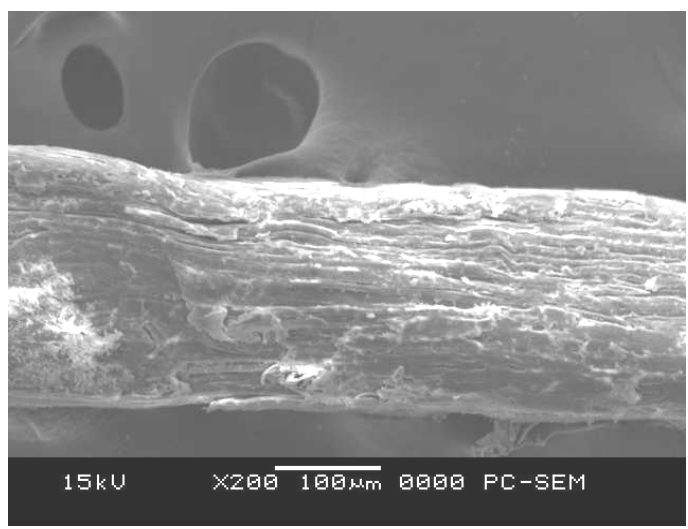

Fig. 4.(a) Untreated coir fibre.

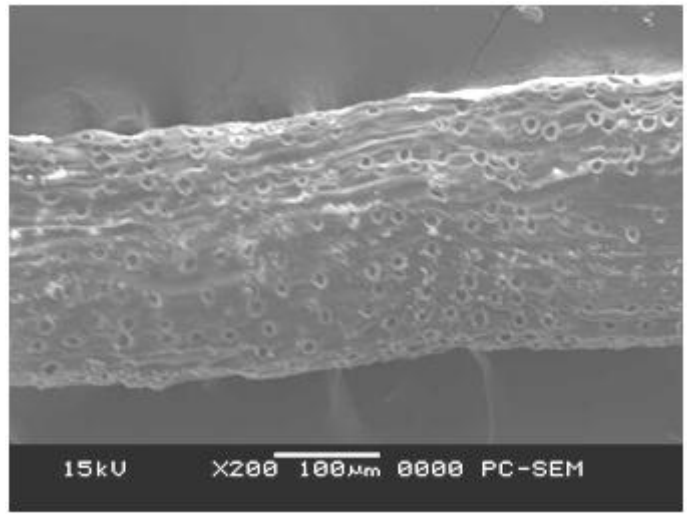

Fig. 4. (b) Treated coir fibre.

Fig. 5 shows the structure of tyre particles. The image revealed that these particles having irregular shape size with multi-surface on its appearance. This characteristic may offer a better damping in composite formed due to more interaction occurred between tyre particles and matrix material at their interface region [16]. Damping helps to dissipate the kinetic energy e.g. noise or vibration found in composite via interaction or frictional of fillers and matrix [21].

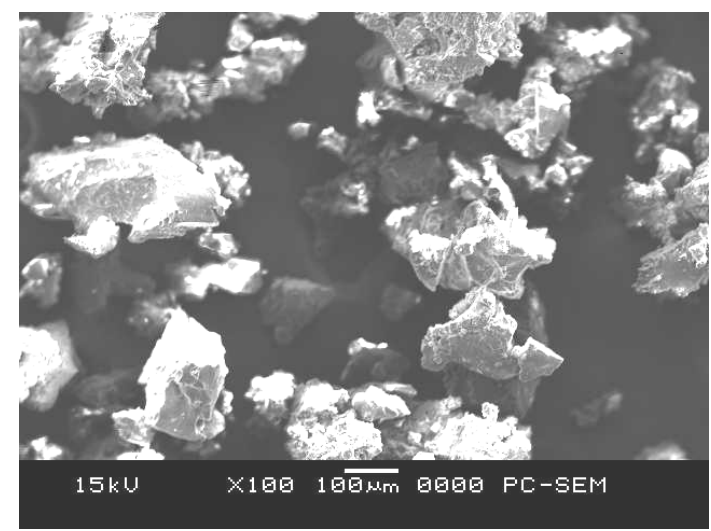

Fig. 5. Tyre particles. 
TABLE II: XRF TRACE OF $\mathrm{CH}_{2}$ IN COIR FIBRES

\begin{tabular}{cccc}
\hline \multicolumn{2}{c}{ Untreated Coir } & \multicolumn{2}{c}{ Treated Coir } \\
\hline Elements & Concentration [\%] & Elements & Concentration [\%] \\
$\mathrm{CH}_{2}$ & 99.100 & $\mathrm{CH}_{2}$ & 99.600 \\
$\mathrm{Ca}$ & 0.025 & $\mathrm{Al}$ & 0.008 \\
$\mathrm{Cl}$ & 0.282 & $\mathrm{Ca}$ & 0.338 \\
$\mathrm{Fe}$ & 0.005 & $\mathrm{Fe}$ & 0.002 \\
$\mathrm{~K}$ & 0.414 & $\mathrm{~K}$ & 0.001 \\
$\mathrm{Mg}$ & 0.030 & $\mathrm{P}$ & 0.046 \\
$\mathrm{P}$ & 0.058 & $\mathrm{~S}$ & 0.005 \\
$\mathrm{~S}$ & 0.014 & $\mathrm{Si}$ & 0.016 \\
$\mathrm{Si}$ & 0.087 & $\mathrm{Zn}$ & 0.002 \\
\hline
\end{tabular}

\section{B. Chemical Composition of Fillers}

To our knowledge, coir fibres is a natural fibres which mainly formed by cellulose, hemicelluloses, lignin, and pectin [9], [22]. Hence, the chemical composition of coir fibres should be majority with hydrocarbon e.g. $\mathrm{C}_{\mathrm{n}} \mathrm{H}_{2 \mathrm{n}}$, which is organic compound consisting of carbon and hydrogen [23]. Hydrocarbons from which one hydrogen atom has been removing are functional groups, called hydrocarbyls [23]. Reference [22] indicated that the cellulose, hemicelluloses, and lignin are chemically formed by hydrocarbon or hydrocarbyls groups. These can be proven on XRF trace of hydrocarbon $\left(\mathrm{CH}_{2}\right)$ in untreated and treated coir fibres in this study (refer to Table II). The results show that in both cases, more than $99 \%$ in coir are forming by $\mathrm{CH}_{2}$. For treated coir, the $99.6 \%$ of $\mathrm{CH}_{2}$ showing the effective of treatment process for removed the impurities on surface of coir.

The results of XRF in Table III indicated the tyre particles are mainly formed by aromatic oils, rubber hydrocarbon (RHC) and carbon black, since $96.9 \%$ of $\mathrm{CH}_{2}$ was contained in tyre particles [10]. Aromatic oils are come from kind of hydrocarbon in chemical [30]. The result actually match with the Material Specification provide by Yong Fong Rubber Industries that is about $10 \pm 3 \%$ of tyre is aromatic oils, $30 \pm$ $5 \%$ is carbon black and $52 \pm 5 \%$ is rubber hydrocarbon (RHC) The actual rubber type in tyre particles is unknown, but the suppliers described the tyre particles as SBR rubber crumb in Material Specification provides. However, it is believed that the tyre particles contain also the natural rubber since they are collected from recycled truck tyre. It is reported that truck tyre contains about $\pm 30 \%$ of natural rubber [10]. Besides, the small amount of $\mathrm{Zn}$ and $\mathrm{S}$ found in XRF trace were used to facilitate the vulcanization process during tyre production [10].

\section{Thermal profiles of fillers}

The results of thermogravimetric analysis (TGA) for coir fibres are shown in Fig. 6 (TG and DTG curves) and it is summarized in Table IV. It can be seen that the thermal profiles of coir fibres are characterized by three stages. For untreated and treated coir, the first stage up to $150^{\circ} \mathrm{C}$ is corresponding to the evaporation of water [12], [24]. The mass loss occurred in this stage is $10-12 \%$.

The thermal profile of second stage in coir fibres show different in between untreated and treated coir. Refers to the Fig. 6(a), the second stage of untreated coir occurred in temperature range of $230^{\circ} \mathrm{C}-300^{\circ} \mathrm{C}$ whereas it was occurred in temperature range of $250^{\circ} \mathrm{C}-343^{\circ} \mathrm{C}$ for treated coir, both are attributed to the decomposition of cellulose in fibres [12],
[24], [25]. The thermal profiles in this case, shown alkaline treatment had made influenced on the thermal degradation behavior of fibres. This promoting an increase in temperature at which the thermal degradation took place. It may due to the removal of some easily hydroxyl substances, which decompose earlier than the major organic compound, hence leading a high thermal stable at second as well as third stage of decomposition for treated coir [24]. According to the Table IV, the third stage up to $530^{\circ} \mathrm{C}$ is attributed to the degradation of lignin in fibres [12], [24], [25]. Besides, it was reported that the hemicelluloses in coir is start degraded at about $190^{\circ} \mathrm{C}$ [24].

\begin{tabular}{cc} 
ACETONE TABLE III: XRF TRACE OF $\mathrm{CH}_{2}$ IN TYRE PARTICLES \\
\hline Elements & Concentration $(\%)$ \\
\hline $\mathrm{CH}_{2}$ & 96.9 \\
$\mathrm{Al}$ & 0.033 \\
$\mathrm{Br}$ & 0.036 \\
$\mathrm{Ca}$ & 0.133 \\
$\mathrm{Cl}$ & 0.011 \\
$\mathrm{Co}$ & 0.013 \\
$\mathrm{Cu}$ & 0.006 \\
$\mathrm{Fe}$ & 0.043 \\
$\mathrm{~K}$ & 0.041 \\
$\mathrm{P}$ & 0.068 \\
$\mathrm{~S}$ & 0.996 \\
$\mathrm{Si}$ & 0.326 \\
$\mathrm{Ti}$ & 0.003 \\
$\mathrm{Zn}$ & 1.414 \\
\hline
\end{tabular}

Based on Fig. 6(b), three peaks were found on DTG curves. The peak values showing the temperature of maximum rate of weight losses that is the critical temperature of e.g. cellulose and lignin on decomposed. These peaks also revealed the high thermal stable of treated coir in second and third stage of its thermal profile. The peaks was found on $319.1^{\circ} \mathrm{C}$ (second stage) and $413.7^{\circ} \mathrm{C}$ (third stage) for treated coir, as compared with those found on $272.3^{\circ} \mathrm{C}$ (second stage) and $376.2^{\circ} \mathrm{C}$ (third stage) for untreated coir.

TABLE IV: TG RESULTS FOR SHORT COIR FIBRES

\begin{tabular}{cccc}
\hline $\begin{array}{c}\text { Coir } \\
\text { Fibres }\end{array}$ & $\begin{array}{c}\text { Transition } \\
\text { Temperature } \\
\text { Range }\left[{ }^{\circ} \mathrm{C}\right]\end{array}$ & $\begin{array}{c}\text { Temperature of } \\
\text { Maximum Rate of } \\
\text { Weight Loss }\left[{ }^{\circ} \mathrm{C}\right]\end{array}$ & $\begin{array}{c}\text { Weight Loss } \\
{[\%]}\end{array}$ \\
\hline Untreated & $30-150$ & 70.2 & 12.125 \\
& $150-300$ & 272.3 & 42.938 \\
Treated & $300-530$ & 376.2 & 43.638 \\
& $30-150$ & 69.9 & 10 \\
& $150-343$ & 319.1 & 50.375 \\
& $343-530$ & 413.7 & 36.456 \\
\hline
\end{tabular}

For tyre particles, the TG and DTG curves shown that there are three decomposition ranges occurred at their thermal profile (refers to Fig. 7). The first decomposition stage from $200^{\circ} \mathrm{C}-350^{\circ} \mathrm{C}$ comes for volatiles materials in tyre e.g. extender oil [26]. The second decomposition stage from $350^{\circ} \mathrm{C}-510^{\circ} \mathrm{C}$ is because of the degradation of polymer in tyre, whereas the third stage begun at $510^{\circ} \mathrm{C}$ is caused by degradation of carbon black [26]. Hence, the profile revealed that rubber element start to decompose at $350^{\circ} \mathrm{C}$ and it reached a maximum rubber loss at temperature of $410.9^{\circ} \mathrm{C}$. Table V illustrated the summaries of thermal profile of tyre particles in TG and DTG curves. 


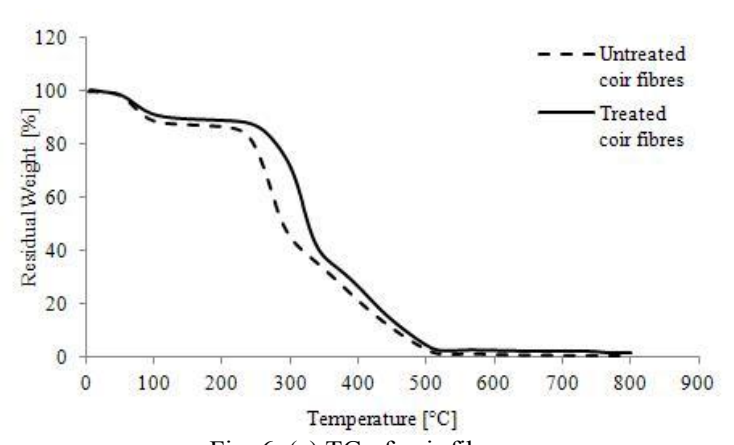

Fig. 6. (a) TG of coir fibres.

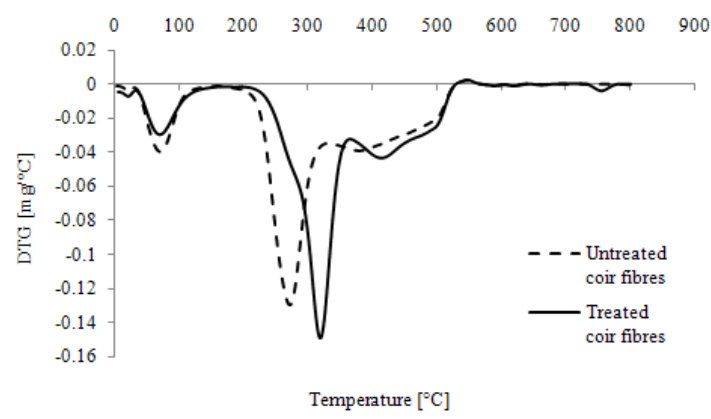

Fig. 6. (b) DTG of coir fibres.

From Fig. 7, it was observed that a small peak was found on $54.9^{\circ} \mathrm{C}$ in temperature range of $5^{\circ} \mathrm{C}-200^{\circ} \mathrm{C}$. This decomposition stage is actually caused by the moisture contains in surface of tyre but not contains in tyre itself. The moisture may come from the environment due to the tyre particles was kept in a box without fully closed. Besides, it was noticed that the maximum peak for thermal degradation of rubber elements in this study is a bit different with those observed in literature that is $504^{\circ} \mathrm{C}$ [26]. This may due to the different type of tyre particles are selected for studied. As said, the tyre particles are come from truck tyre.

The thermal profiles of fillers are considered important to flexible PU foam composites production. This is because exothermic was found during the reaction of polyol and isocyanate, and during the blowing reaction in foam production [2]. The maximum temperature is up to $140^{\circ} \mathrm{C}$ with blowing reaction occurred [2]. Thus, only fillers with high thermal stable are suitable to use as fillers incorporate with flexible PU foam. Through thermal properties study, both of the treated coir and recycled tyre are proved on having the potential to reinforce the flexible PU foams via composite formation. This is because the degradation temperature of organic compounds (in coir) and rubber elements (in tyre) shown much higher than the $140^{\circ} \mathrm{C}$.

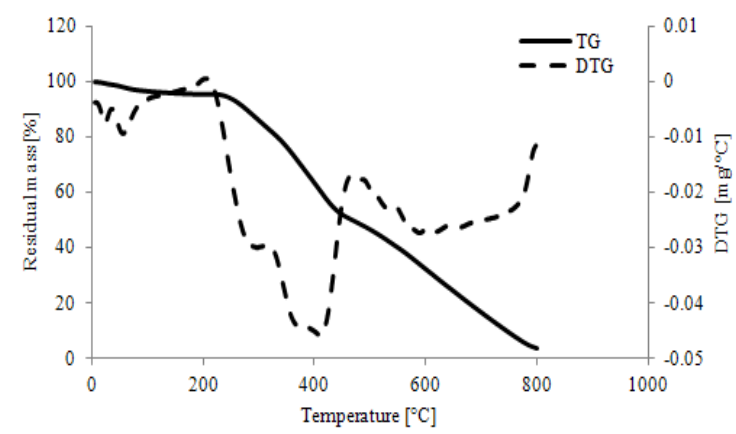

Fig. 7. TG and DTG of tyre particles.
TABLE V: TG RESULTS FOR TYRE PARTICLES

\begin{tabular}{cccc}
\hline & $\begin{array}{c}\text { Transition } \\
\text { Temperature Range } \\
{\left[{ }^{\circ} \mathrm{C}\right]}\end{array}$ & $\begin{array}{c}\text { Temperature of } \\
\text { Maximum Rate of } \\
\text { Weight Loss }\left[{ }^{\circ} \mathrm{C}\right]\end{array}$ & $\begin{array}{c}\text { Weight } \\
\text { Loss } \\
{[\%]}\end{array}$ \\
\hline Tyre & $200-350$ & 289.1 & 19.102 \\
Particles & $350-510$ & 410.9 & 31.018 \\
& $>510$ & 587.3 & 41.916 \\
\hline
\end{tabular}

\section{Effect of Fillers to Foams Production}

One important factor to make flexible PU foam composite is the presence of water in polymer matrix. The water can act as chemical blowing agent due to released carbon dioxide $\left(\mathrm{CO}_{2}\right)$ when reacting with isocyanate [2], [27]. Hence, extra distilled water was decided add in polyol for obtained an effective rising foams, though the polyol is originally included with small amount of water from supplier. The resulting specimen with distilled water added was observed foaming well compare with specimen without distilled water added (refers to Fig. 8). Therefore, a new blend ratio of PU formation was developed for this study that is 100:60:3 (polyol: isocyanate: distilled water).

Flexible PU foam composites were decided produced with loading fraction of $2.5 \mathrm{wt} \%$. This is because foam composites were found not effectively rise once the loading fraction is more than $2.5 \mathrm{wt} \%$, unless more PU content were added to composites. This problem was happen because the additional fillers caused a rapidly increased of viscosity in the mixture during foam production [6]. This behavior can be clearly seen and feel when mixing the polyol and treated coir fibres using a handmixer in this study. The mixture become more viscous and become tar-like consistency when added $5 \mathrm{wt} \%$ of treated coir fibres or tyre particles, even with mixing of both. The increasing of viscosity in mixtures causes the specimen no longer to foaming properly. The structure of specimen produced in this case is similar with the specimen produced without distilled water added (refers to Fig. 8). It was reported that similar results were obtained in literature which increased the loading fraction of carbon nanotube to more than $0.2 \mathrm{wt} \%$ would caused a fail on flexible PU foam composite formation [6].

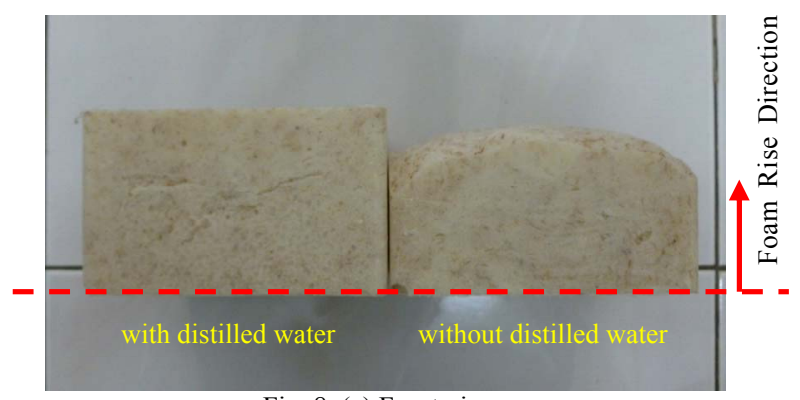

Fig. 8. (a) Front view.

Moreover, at the same loading fraction, flexible PU mixed with coir fibres was found on created more viscosity, if compare with those mixed with tyre particles during production. This is actually because of coir fibres having large surface areas contact with polyol thus; more friction is created in between. For tyre particles, their micro-particle size resulted small friction during components mixing stage. Hence, the percentage of fail in obtained proper foams for composite with coir fibres inclusion is higher than those with 
tyre particles inclusion though they are produced by using similar parameters (i.e. mould, loading fraction, and temperature). Similar observation were obtained if compare the flexible PU foam reinforced with $2.5 \mathrm{wt} \%(80 \mathrm{~F} 20 \mathrm{P})$ and $2.5 \mathrm{wt} \%(80 \mathrm{P} 20 \mathrm{~F})$. The former one was found easy to obtained imperfect foam during production.

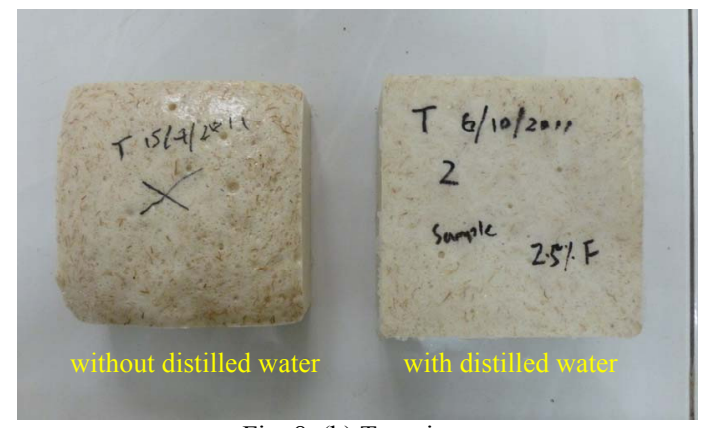

Fig. 8. (b) Top view.

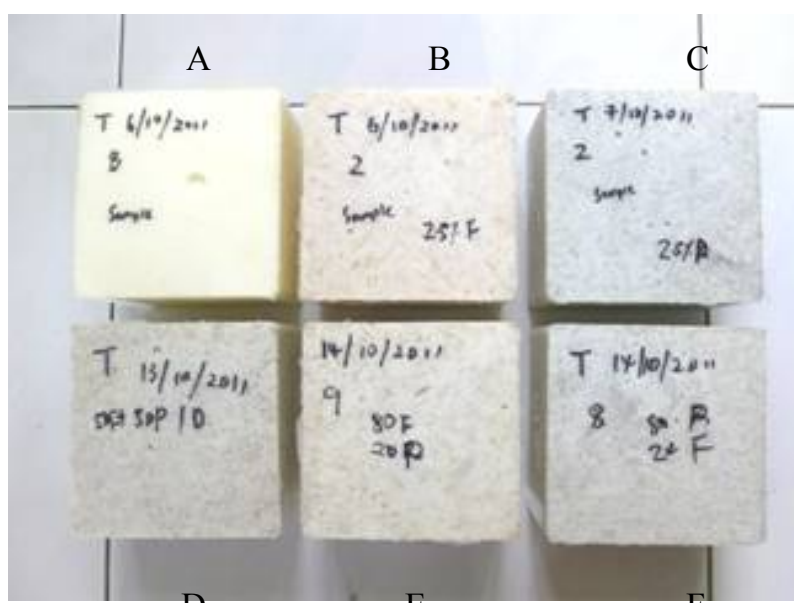

Fig. 9. Samples of flexible PU foatns reinforced with $2.5 \mathrm{w} \%$ of fillers, $\mathrm{A}=\mathrm{PU}$ foam, $\mathrm{B}=\mathrm{PU}+2.5 \mathrm{wt} \% \mathrm{~F}, \mathrm{C}=\mathrm{PU}+2.5 \mathrm{wt} \% \mathrm{P}, \mathrm{D}=\mathrm{PU}+2.5 \mathrm{wt} \%(50 \mathrm{~F} 50 \mathrm{P})$, $\mathrm{E}=\mathrm{PU}+2.5 \mathrm{wt} \%(80 \mathrm{~F} 20 \mathrm{P})$, and $\mathrm{F}=\mathrm{PU}+2.5 \mathrm{wt} \%(80 \mathrm{P} 20 \mathrm{~F})$.

Besides, it was noticed that added fillers to flexible PU foam may increase the foam formation time [6]. Normally, pure PU foam is removed from mould after 6 minutes from the PU mixtures poured into mould. However, for foam composites, 10-15 minutes was required in order to make sure the cellular structure is fully formed and solidified. The time consume for foam solidified indicated a lower foaming rate in foam composite production.

Fig. 9 presents the images of flexible PU foams reinforced with coir fibres, tyre particle, and mixed of both. According to the images, the samples developed show fillers are dispersed evenly in the matrix material. The colour of pure foam was observed changes from yellowish to light-brown for foams reinforced with larger percentage of coir fibres. Meanwhile, it is changes to light-grey for foams reinforced with large percentage of tyre particles.

\section{E. Microstructure of foam composites}

Fig. 10 and Fig. 11 show the SEM micrographs of samples produced in this study. The SEM observations show that there was not much different in between images captured from surface perpendicular to the foaming direction and images captured from surface parallel to the foaming direction. All the foams show anisotropic, though some of them (e.g. structures of $\mathrm{PU}+2.5 \mathrm{wt} \% \mathrm{~F}$ and
PU+2.5wt\%(50F50P) in Fig. 10) seem like having uniform cell structures throughout. Literature studied has been mentioned that almost all man-made foams are anisotropic [28].
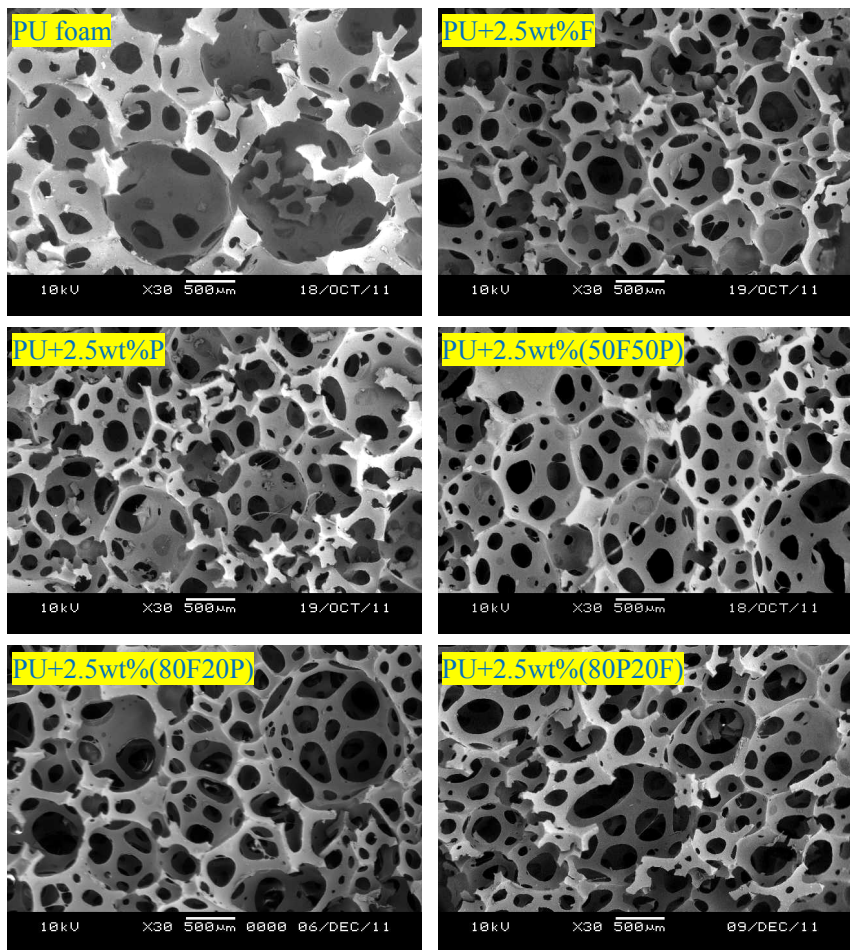

Fig. 10. SEM micrographs of foam composites which captured from the surface perpendicular to the foaming direction.

Based on the SEM micrographs, the flexible PU foam composites are found on having open-cells cellular structures. The open-cell in structures contained many small open-windows located on the cell wall and these cause the struts formed in between the open windows [2].

Compare the cellular structures of all the foam composites, larger cells were found on pure PU foams' structure no matter it is observed in surface perpendicular or parallel to the foam direction. This can be proven by the cell size measurement carried out by analytical SEM software. Fig. 12 illustrated the mean cell size of foams in two different surfaces. The mean cell size of pure PU foam is $23.785 \%$ larger than the foams reinforced with $2.5 \mathrm{wt} \%(80 \mathrm{P} 20 \mathrm{~F})$ in case of image captured from surface perpendicular to foaming direction whereas it is $34.884 \%$ larger than foams reinforced with $2.5 \mathrm{wt} \% \mathrm{~F}$ in case of image captured from surface parallel to the foaming direction. The latter foams in both cases were found having the smallest mean cell size if compare with six sample of foams.

Besides, the SEM micrographs show that thicker struts were formed on the cell walls of pure foam. This is because large surface areas of cell walls were obtained in PU foam with bigger cell size. For foam composites, the cellular structures are formed by many small cells which included many open-windows on the cell walls. Hence, thinner struts were found in small cells. Fig. 10 and Fig. 11 can observed the thickness of struts in both surfaces of foams. Among all the foam composites, foams reinforced with $2.5 \mathrm{wt} \%$ (50F50P) seem like having thicker struts on its structure since the cells developed are larger than other foam composites (refers to 
Fig. 12). According to the Fig. 12, the PU $+2.5 w t \% F$ and $\mathrm{PU}+2.5 \mathrm{wt} \% \mathrm{P}$ having a majority of small cells in cellular structures if accord to the standard deviation in bar chart whereas PU+2.5wt\%(80F20P) and PU+2.5wt\%(80P20F) contain variable cell sizes in foams. The standard deviation of cell size for PU+2.5wt\%(80F20P) and PU+2.5wt\%(80P20F) showing a large gap in between. All of these characteristics can be observed in micrographs captured by SEM.
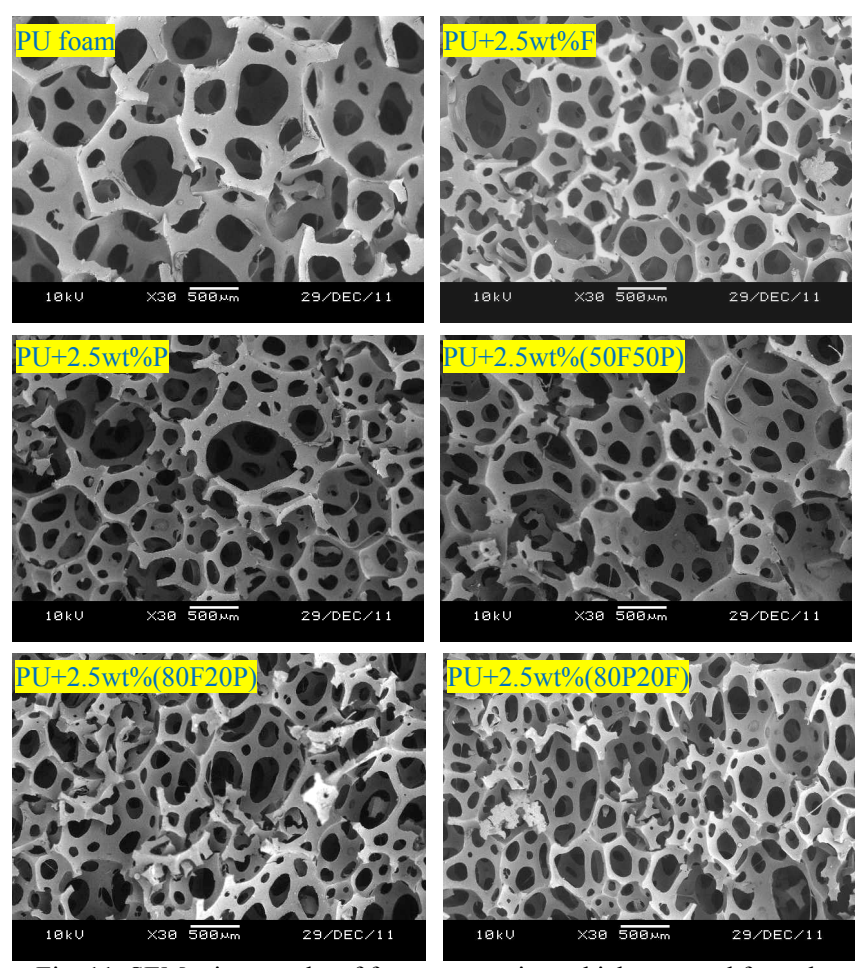

Fig. 11. SEM micrographs of foam composites which captured from the surface parallel to the foaming direction.

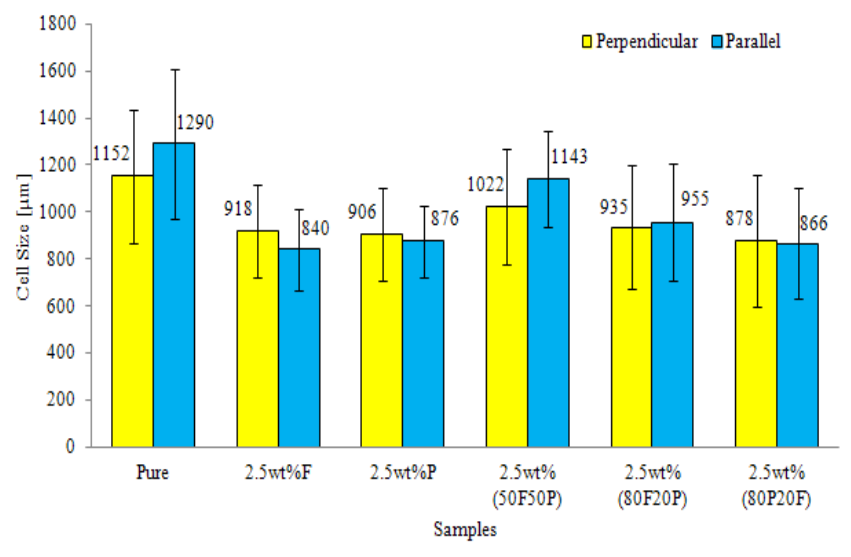

Fig. 12: Mean cell size of foam composites

In overall, the results of morphology study indicated that fillers tend to modify the microstructure of PU foam to become smaller cell size and thus higher cell density. Similar observations were found on literatures also [6], [18]. Therefore, the morphology studied agreed with fillers may serve as nucleating agent that promote the cell nucleation. Which resulting a higher cell density at the final formed [18]. Meanwhile, the increase of viscosity during foam production hinders the cells growth and thus leading to smaller cell size formation [6], [18]. Furthermore, it was reported that cellular structure with smaller cell size and higher cell density formation could improved the damping performance in composite [29]. Hence, the foam composites designed and developed in this study may have a better damping property as compared with pure flexible PU foam.

\section{CONCLUSION}

Five types of flexible PU foam composites which formed with $2.5 \mathrm{wt} \%$ of fillers in combination of coir fibres only, tyre particles only, and combined of both were developed. The treated coir (treated with $5 \% \mathrm{NaOH}$ ) was used to reinforce the flexible PU foams as compared with untreated coir due to a good bonding may obtained in between matrix and fibres. There was no any treatment process selected for tyre particles.

The results of chemical analysis indicated that more than $99 \%$ in coir fibres are organic compound whereas it is $96.9 \%$ in tyre particles formed by aromatic oil, carbon black and rubber hydrocarbon. The thermal analysis revealed that it is possible to incorporate coir fibres and tyre particles in flexible PU since the decomposition temperature of coir $\left(250^{\circ} \mathrm{C}\right)$ and rubber elements in tyre $\left(350^{\circ} \mathrm{C}\right)$ are much higher than the heat release during exothermic of PU production.

During the foam production, effect of fillers on viscosity increase in PU mixture causes the foam composites easily to become failed or imperfect. This case was especially serious on foam reinforced with coir fibres or higher percentage of coir fibres though all the foams were fabricated with similar parameters.

Besides, the SEM images indicated that structures of foams are anisotropic. The foam composites captured by SEM are found on having open-cells cellular structure which formed by many small cells and thus, higher cell density. The mean cell sizes of foam composites were totally smaller than the flexible PU foam.

Last but not least, the developed foams can be used as cushioning material in applications of automotive seat, in packaging system, or acoustic room since the cellular structure obtained shown its may offers better damping if compare with structure of pure flexible PU foam. Hence, further research will concentrate on analysis the sound and vibration absorption of foams.

\section{ACKNOWLEDGMENT}

The authors would like to thank En. Fazlannuddin Hanur bin Harith, and En. Shahrul Mahdi bin Samsudin, the technicians of Polymer and Ceramic Laboratory, UTHM for given many support on fillers preparation, foams fabrication, and testing setup. Besides, the authors would like to thank En. Anuar bin Ismail, the technician of Material Science Laboratory, UTHM for setting up the SEM machine.

\section{REFERENCES}

[1] L. Zhang, "Structure-Property Relationship of Polyurethane Flexible Foam Made From Natural Oil Polyols," Ph.D. dissertation, Chemical Engineering \& Material Science, University of Minnesota, Minnesota, 2008.

[2] D. Klempner and V. Sendijarevic, Polymeric Foams and Foam Technology, $2^{\text {nd }}$ ed., Munich: Hanser, 2004. 
[3] R. D. Widdle, "Measurement and Modelling of the Mechanical Properties of Flexible Polyurethane Foam," Ph.D. dissertation, School of Mechanical Engineering, Purdue University, West Lafayette, Indiana, 2005.

[4] G. K. Latinwo, D. S. Aribike, A. A. Susu and S. A. Kareem, "Effect of Differnet Filler Treatment on the Morphology and Mechnical Properties of Flexible Polyurethane Foam Composites," Nature and Science, vol. 8, no. 6, pp. 23-26, 2010a.

[5] D. d. Mello, S. H. Pezzin and S. C. Amico, "The effect of post-consumer PET particles on the performance of flexible polyurethane foams," Polymer Testing, vol. 28, pp. 702-708, 2009.

[6] R. Verdejo, R. Stampfli, M. Alvarez-Lainez, S. Mourad, M. A. Rodriguez-Perez, P. A. Bruhwiler and M. Shaffer, "Enhanced acoustic damping in flexible polyurethane foams filled with carbon nanotubes," Composites Science and Technology, vol. 69, pp. 1564-1569, 2009.

[7] G. K. Latinwo, D. S. Aribike, L. O. Oyekunle, A. A. Susu and S. A. Kareem, "Effects of calcium carbonate of different composition and particles size distribution on the mechanical properties of flexible polyurethane foam," Nature and Science, vol. 8, no. 9, 2010b.

[8] L. Ting, M. LiangLiang, L. Fuwei, J. Wuzhou, H. Zhaobo and F. Pengfei, "Preparation, Structure, and Properties of Flexible Polyurethane Foams Filled with Fumed Silica," Journal of Natural Sciences, vol. 16, no. 1, pp. 029-032, 2011.

[9] S. Taj, M. A. Munawar and S. Khan, "Natural Fiber-Reinforced Polymer Composite," in Proc. of the Pakistan Academic of Science, 2007, vol. 44, no. 2, pp. 129-144

[10] V. L. Shulman, Tyre Recycling, vol. 15, Shropshire: Rapra Technology, 2004.

[11] S. N. Monteiro, L. A. H. Terrones and J. R. M. D'Almeida, "Mechanical performance of coir fiber/polyester composites," Polymer Testing, vol. 27, pp. 591-595, 2008.

[12] W. S. Chan, M. I. Idris and M. I. Ghazali, "Flexible Polyurethane Foams Filled with Coconut Coir Fibres and Recycled Tyre. Part I Production and Morphology," Advanced Material Research, vol. 488-489, pp. 759, 2012a.

[13] R. F. Gibson, Principles of Composite Material Mechanics, $2^{\text {nd }}$ ed., Boca Raton: CRC Press, 2007.

[14] V. G. Geethamma, G. Kalaprasad, G. Groeninckx and S. Thomas, "Dynamic mechanical behaviour of short coir fiber reinforced natural rubber composites," Composites:Part A, vol. 36, pp. 1499-1506, 2005.

[15] I. Z. Bujang, M. K. Awang and A. E. Ismail, "Influence of Fiber Volume Fraction on the Tensile Properties and Dynamic Characteristics of Coconut Fiber Reinforced Composite," Journal of Science and Technology, vol. 1, no. 1, pp. 55-71, 2009.

[16] H. R. Sankar, P. V. Krishna, V. B. Rao and P. B. Babu, "The effect of natural rubber particle inclusions on the mechanical and damping properties of epoxy-filled glass fibre composites," in Proc. of the Institution of Mechanical Engineers, Part L: Journal of Material Design and Applications, 2010, vol. 224, pp. 63.

[17] H. Gu, "Tensile behaviours of the coir fibre and related composites after $\mathrm{NaOH}$ treatment," Material and Design, vol. 30, pp. 3931-3934, 2009.

[18] Z. X. Xin, X. Z. Zhang, K. Pal, J. U. Byeon, S. H. Lee and J. K. Kim, "Study of microcellular injection-molded polypropylene/waste ground rubber tire powder blend," Materials and Design, vol. 31, pp. 589-593, 2010.

[19] W. S. Chan, M. I. Idris and M. I. Ghazali, "Flexible Polyurethane Foams Filled with Coconut Coir Fibres and Recycled Tyre. Part II: Compression and Energy Absorption," Advanced Material Research, vol. 488-489, pp. 767, 2012b.

[20] W. Wei and H. Gu, "Characterisation and utilization of natural coconut fibres composites," Materials and Design, vol. 30, pp. 2741-2744, 2009.

[21] A. Chandra, S. P. Singh and K. Gupta, "Damping studies in fiber-reinforced composites-a review," Composite Structure, vol. 46, pp. 41-51, 1999.

[22] M. J. John and R. D. Anandjiwala, "Recent Developments in Chemical Modification and Characterization of Natural Fiber-Reinforced Composites," Polymer Composites, vol. 29, no. 2, pp. 187-207, 2008.

[23] Information on http://en.wikipedia.org/wiki/Hydrocarbon\#cite note-1

[24] M. F. Rosa, B. Chiou, E. S. Medeiros, D. F. Wood, T. G. Williams, L. H. Mattoso, W. J. Orts and S. H. Imam, "Effect of fiber treatment on tensile and thermal properties of starch/ethylene vinyl alcohol copolymers/coir biocomposites," Bioresource Technology, vol. 100, pp. 5196-5202, 2009.

[25] C. G. Mothe and I. C. de Miranda, "Characterization of sugarcane and coconut fibers by thermal analysis and FTIR," Journal of Thermal Analysis and Calorimetry, vol. 97, pp. 661-665, 2009.

[26] H. Scuracchio, D. A. Waki and M. da Silva, "Thermal Analysis of Ground Tire Rubber Devulcanized by Microwaves," Journal of Thermal Analysis and Calorimetry, vol. 87, pp. 893-897, 2007.

[27] Y. Li, H. F. Ren and A. J. Ragauskas, "Rigid polyurethane foam reinforced with cellulose whiskers: Synthesis and characterization," Nano-Micro Letters, vol. 2, no. 2, pp. 89-94, 2010.

[28] L. J. Gibson and M. F. Ashby, Cellular Solids: Structure and properties, $2^{\text {nd }}$ ed., Cambridge: Cambridge University Press, 1997.

[29] X. H. Dai, Z. M. Liu, Y. Wang, G. Y. Yang, J. Xu and B. X. Han, "High damping property of microcellular polymer prepared by friendly environmental approach," J. of Supercritical Fluids, vol. 33, pp. 259-267, 2005.

[30] N. Kumar, R. Khandelwal, P. Meena, T. Chaki, D. Mahla and S. Dasgupta, "Chemical Analysis on Different Oils use in Tyre Tread Cap Compound," Internatinal Journal of Chemical, Environmental and Pharmaceutical Research, vol. 2, no. 1, pp. 12-19, 2011.

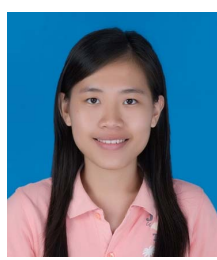

Chan Wen Shan is a master candidate from Faculty of Mechanical and Manufacturing Engineering, Universiti Tun Hussein Onn Malaysia (UTHM). She obtained her bachelor degree in Mechanical Engineering from Universiti Tun Hussein Onn (UTHM) at 2010. Currently, she's research direction for her master project is design and develops flexible PU foam composites, which are used to absorb kinetic energies.

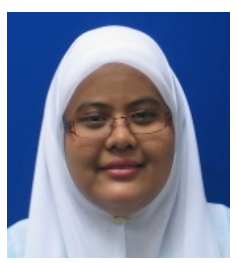

Maizlinda Izwana Idris is a senior lecturer of the Dept. of Materials and Design Engineering, Faculty of Mechanical and Manufacturing Engineering, Universiti Tun Hussein Onn Malaysia (UTHM). She obtained her B. Eng and MSc in Materials Engineering from the University of Science Malaysia in the year of 2000 and 2001, respectively. In year 2010, she completed her $\mathrm{PhD}$ in Material Science and Engineering from the University of New South Wales, Australia. She joined UTHM (formerly known as KUiTTHO) as a lecturer in year 2002, and was involved actively in teaching and research in the field of advanced materials. At present, besides as a senior lecturer, she is the head of department- Office of Strategic Management and Quality, Universiti Tun Hussein Onn Malaysia (UTHM). Her specialization research interests are in composite and advanced materials.

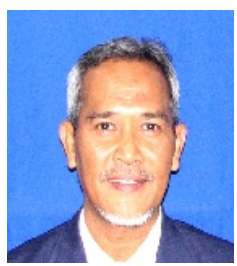

Mohd Imran Ghazali is a professor in the Faculty of Mechanical and Manufacturing Engineering, Universiti Tun Hussein Onn Malaysia (UTHM). He obtained his MSc in Noise and Vibration from the Institute of Sound and Vibration Research (ISVR), University of Southampton, BSc in Mechanical Engineering from the University of Glasgow, Scotland and his Diploma in Mechanical from the University Technology Malaysia (UTM). He started his career as assistant lecturer at the University Technology Malaysia in 1978 and was transferred to UTHM in 1993 (formerly known as KUiTTHO). At present, he's the professor in the Dept. of Mechanics, Faculty of Mechanical and Manufacturing Engineering. He has about 30 years experience of teaching in UTM and UTHM, which involve teaching in Engineering Mechanics (Static and Dynamics), Strength of Materials, Mechanics of Machines, Noise and Vibration. His specialization research interests are in Noise and Vibration, Condition Based Monitoring, Preventive Maintenance and Acoustic. 